\title{
Динаміка показників захворюваності та смертності від раку нирки в Україні: сучасний стан проблеми
}

\author{
YU. O. MYTSYK \\ Lviv National Medical University by Danylo Halytskyi
}

\section{DYNAMICS OF THE MORBIDITY AND MORTALITY RATES IN PATIENTS WITH RENAL CELL CARCI- NOMA IN UKRAINE: THE STATE OF THE PROBLEM}

\begin{abstract}
Нирковоклітинний рак (НКР) становить близько 3 \% усіх злоякісних пухлин у дорослих і понад 90 \% усіх новоутворень нирки. За останнє 10-річчя відзначають значне підвищення захворюваності на цю пухлину, про що свідчать статистичні дані. Аналіз показників захворюваності та смертності на НКР в Україні здійснювався за даними Бюлетеня Національного канцер-ресстру України 1999-2012 рр. Було проаналізовано такі показники: грубі (звичайні) показники захворюваності та смертності, стандартизовані за віком показники захворюваності та смертності, широко вживаний для порівняння показників між країнами світу світовий стандарт населення, а також український стандарт населення, обчислений на основі вікової структури населення України у 2000 р. Проведений аналіз динаміки показників захворюваності на НКР у 1999-2012 рр. продемонстрував їх зростання як в Україні в цілому, так і в кожній окремій області. У 1999 р. показник захворюваності (світовий стандарт) на НКР в Україні становив 5,6 а в 2012 р. - 8,1. При цьому в чоловіків даний показник перевищував такий у жінок у середньому в 2 рази. Аналіз динаміки показників смертності внаслідок НКР у 1999-2012 рр. засвідчив чітку тенденцію до їх зростання по Україні в цілому та в кожній окремій області. В 1999 р. показник смертності (світовий стандарт) внаслідок НКР в Україні становив 2,8, а в 2012 р. - 3,2. При цьому даний показник був майже в 3 рази вищий у чоловіків, ніж у жінок. В результаті проведеного дослідження було встановлено чітку тенденцію до зростання показників захворюваності та смертності у хворих із НКР в Україні та ї̈ областях із 1999 до 2012 рр. При цьому спостерігали гендерні особливості - у чоловіків обидва показники значно перевищували такі у жінок. Невпинне зростання захворюваності та смертності у хворих із НКР потребує перегляду протоколів обстеження та лікування такої категорії хворих.
\end{abstract}

\begin{abstract}
Renal cell carcinoma (RCC) accounts for about $3 \%$ of all cancers in adults and $90 \%$ - of all kidney tumors. Over the last decade a significant increase in the incidence of this tumor is being observed, as evidenced by statistical data. The analysis of morbidity and mortality rates of the RCC in Ukraine was performed in accordance with the Bulletin of the National Cancer Registry of Ukraine 1999-2012. The following indicators were analyzed: raw (average) morbidity and mortality by standardized age, incidence of the disease and mortality, widely used for comparisons between countries worldwide standard population and Ukrainian standard population, calculated based on the age structure of the population of Ukraine in 2000. The analysis of the dynamics of the incidence of RCC in 1999-2012 demonstrated its incremental growth in Ukraine as a whole as well as in each particular region. In 1999 the incidence (world standard) of RCC in Ukraine was 5.6 and in 2012 - 8.1. Herewith, the incidence in males exceeded later in females twofold. The analysis of mortality due to RCC in 1999-2012 showed a clear incremental tendency in Ukraine as a whole and in each individual region. In 1999 the mortality rate (world standard) of RCC in Ukraine was 2.8 and 3.2 - in 2012. However, this figure was almost 3 times higher in men than in women. As a result of the conducted study a clear incremental tendency towards increase of the morbidity and mortality in patients with RCC in Ukraine and its regions from 1999 to 2012 was revealed. Herewith, some gender differences were observed - both figures among males were significantly higher than those in females. Continuous increment growth of morbidity and mortality in patients with RCC requires revision of protocols of diagnostics and treatment of such patients.
\end{abstract}

Постановка проблеми і аналіз останніх досліджень та публікацій. Нирковоклітинний рак (НКР) становить близько 3 \% усіх злоякісних пухлин у дорослих і понад $90 \%$ - усіх новоутворень нирки. За останнє 10-річчя відзначають значне підвищення захворюваності на цю пухлину, про що свідчать статистичні дані. Так, в Україні з 1994 до 2004 р. захворюваність підвищилась з 6,6 до 9,4 (грубий показник) на 100 тис. [1] населення, кількість зареєстрованих випадків РН становила 3459 у 1998 р., у 2004 р. - 4466 (зростання на 23 \%). За даними РОНЦ ім. М. М. Блохіна, у Росії цей показник з 1989 до 
1996 р. підвищився у 2 рази [2, 3]. Згідно з даними Всесвітньої організації охорони здоров'я, рак нирки перебуває на 13 місці 3-поміж усіх онкозахворювань за поширенням, близько 70 тис. випадків захворювань на НКР вперше виявляють щороку та приблизно 116 тис. хворих кожного року помирає від цього захворювання [4].

У США захворюваність на НКР становить близько 4 \% від усіх виявлюваних злоякісних новоутворень. Так, у 2012 р. в США було виявлено 64770 нових випадків НКР із тенденцією до частішого виникнення у пацієнтів чоловічої статі у співвідношенні 3:2. Велике дослідження SEER (Surveillance, Epidemiology and End Results) вказало на те, що приблизно в 1 із 69 чоловіків та в 1 із 116 жінок буде діагностовано НКР протягом їхнього життя [5]. Кількість летальних випадків унаслідок цього захворювання сягнула 13500 за 2012 рік. Незважаючи на те, що показник смертності від НКР у США за останні 10 років залишається майже незмінним, спостерігається щорічний ріст захворюваності на дану патологію, що відображено у численних епідеміологічних дослідженнях [6].

Враховуючи вищесказане, проблема моніторингу й аналізу показників захворюваності та смертності на НКР в Україні та її регіонах має вкрай актуальне значення для сучасної онкоурології.

Мета роботи: проаналізувати динаміку показників захворюваності та смертності на НКР в Україні та її регіонах за останні роки.

Матеріали і методи. Аналіз показників захворюваності та смертності на НКР в Україні здійснювався за даними Бюлетеня Національного канцерреєстру України 1999-2012 рр. Було проаналізовано такі показники: грубі (звичайні) показники захворюваності та смертності - кількість нових випадків захворюваності на злоякісні новоутворення (або, відповідно, випадків смерті від злоякісних новоутворень), які відбулися в популяції протягом року, віднесена до середньої чисельності цієї популяції в тому самому році, виражена через показник на 100 тис. населення; стандартизовані за віком показники захворюваності та смертності - показник захворюваності (смертності) населення, розрахований за віковою структурою “стандартного населення” для нівелювання відмінностей у віковому розподілі різних популяцій. За стандартні населення тут вибрані: широко вживаний для порівняння показників між країнами світу світовий стандарт населення, а також украӥнський стандарт населення, обчислений на основі вікової структури населення України у 2000 р.
Результати досліджень та їх обговорення. У результаті проведеного аналізу грубого та стандартизованого показників захворюваності на НКР в Україні за 1999-2012 рр. було констатовано тенденцію до зростання обох показників. Так, у 1999 р. грубий показник захворюваності на НКР складав 8, у 2004 р. - 9,8, у 2005 р. - 10,3, у 2006 р. 10,3, y 2007 p. -11,1, y 2008 p. - 11,5, y 2009 p. - 11,2, у 2010 р. - 11,9, у 2011 р. - 12,3, у 2012 р. - 12,8. При цьому грубий показник захворюваності був у середньому в 1,5 раза вищий у чоловіків, ніж у жінок. Подібну динаміку спостерігали у зміні стандартизованого показника захворюваності на НКР: у 1999 р. він складав 5,6, у 2004 р. - 6,5, у 2005 р. -6,8, y 2006 p. - 6,7, у 2007 p. - 7,4, y 2008 p. - 7,6, у 2009 р. - 7,34, у 2010 р. - 7,6, у 2011 р. - 7,8, у 2012 р. - 8,1. До того ж, даний показник був майже в 2 рази вищий у чоловіків, ніж у жінок. Динаміку змін грубого та стандартизованого показників захворюваності на НКР та їх особливості у чоловіків і жінок відображено на рисунку 1.

Аналіз динаміки змін грубого показника смертності внаслідок НКР в Україні продемонстрував його зростання порівняно з попередніми роками: у 1999 р. він становив 4,3, у 2004 р. - 5,1, у 2005 p. - 4,9, y 2006 p. - 5,1, у 2007 p. - 5,4, y 2008 p. $-5,3$, у 2009 p. - 5,32, у 2010 p. - 5,5, у 2011 p. - 5,4, у 2012 р. - 5,5. У чоловіків цей показник був у середньому в 2 рази вищий, ніж у жінок. Стандартизований показник смертності з приводу НКР зріс у період із 1999 до 2004 р., проте залишався майже незмінним із 2004 до 2012 р. з незначною тенденцією до зростання: у 1999 р. він складав 2,8, y 2004 p. - 3,2, y 2005 p. - 3, y 2006 p. - 3,1, y 2007 p. $-3,3$, у 2008 p. - 3,3, у 2009 p. - 3,2, у 2010 p. - 3,2, у 2011 р. - 3,1, у 2012 р. - 3,2. При цьому даний показник був майже в 3 рази вищий у чоловіків, ніж у жінок. Динаміку змін грубого та стандартизованого показників смертності внаслідок НКР впродовж 1999-2012 рр. відображено на рисунку 2.

При аналізі динаміки змін стандартизованого показника захворюваності (український стандарт) на НКР в Україні та в її областях впродовж 19992012 рр. було встановлено його невпинне зростання порівняно з попередніми роками. Так, у 1999 р. він становив 8,1, у 2004 р. - 9,4, у 2005 р. - 9,8, у 2006 р. 9,8, y 2007 p. - 10,8, y 2008 p. - 11,2, у 2009 p. - 10,82, у 2010 р. - 11,2, у 2011 р. - 11, у 2012 р. - 12,1. При цьому в 2012 р. він був найвищим в таких областях: Сумській - 15,5, Миколаївській - 14, Кіровоградській - 13,8, Рівненській - 13,7 та в Полтавській - 13,7 та найнижчим у Чернівецькій - 7,6, Закарпатській - 


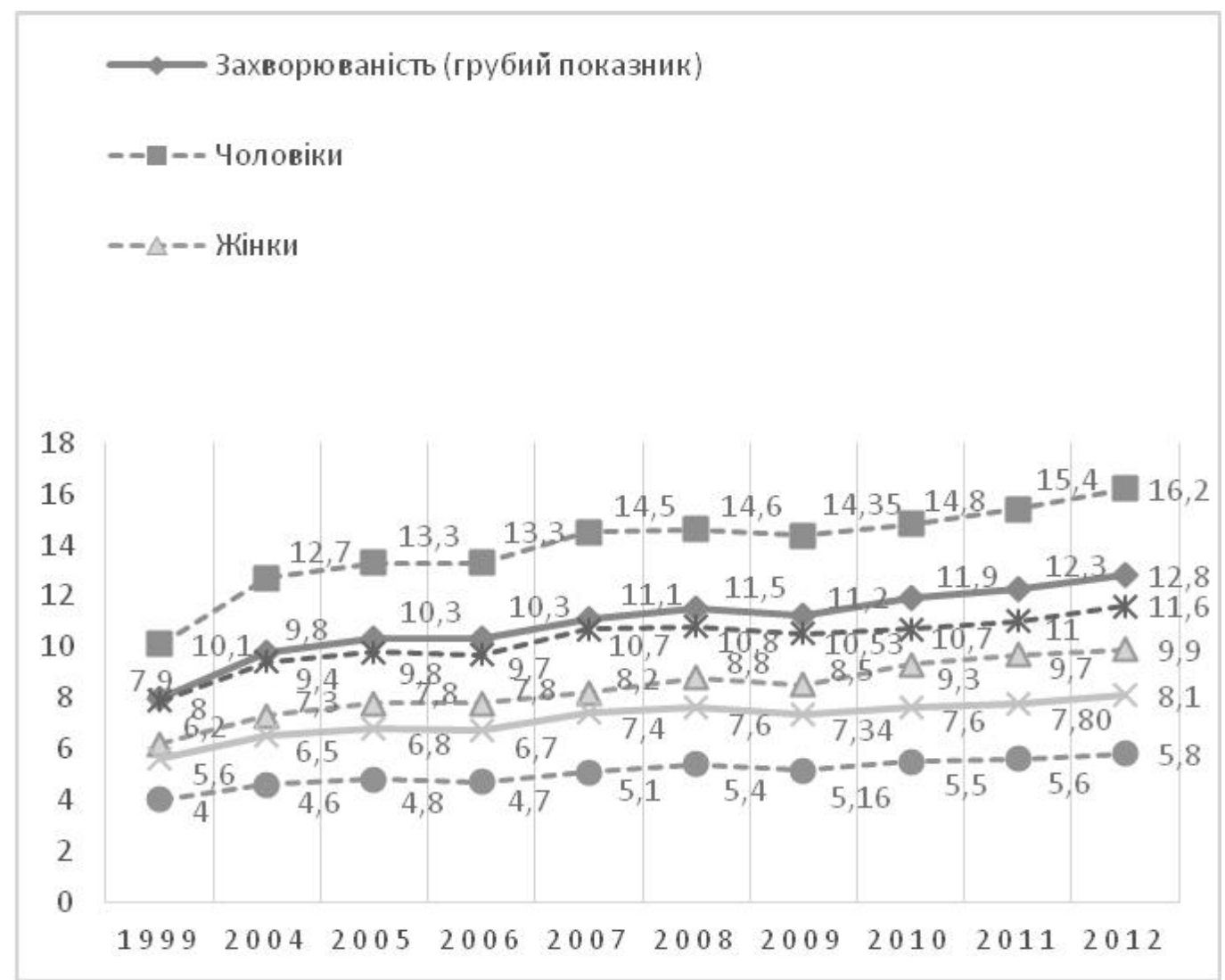

Рис. 1. Динаміка змін грубого та стандартизованого показників захворюваності на НКР в Україні впродовж 1999$2012 \mathrm{pp}$

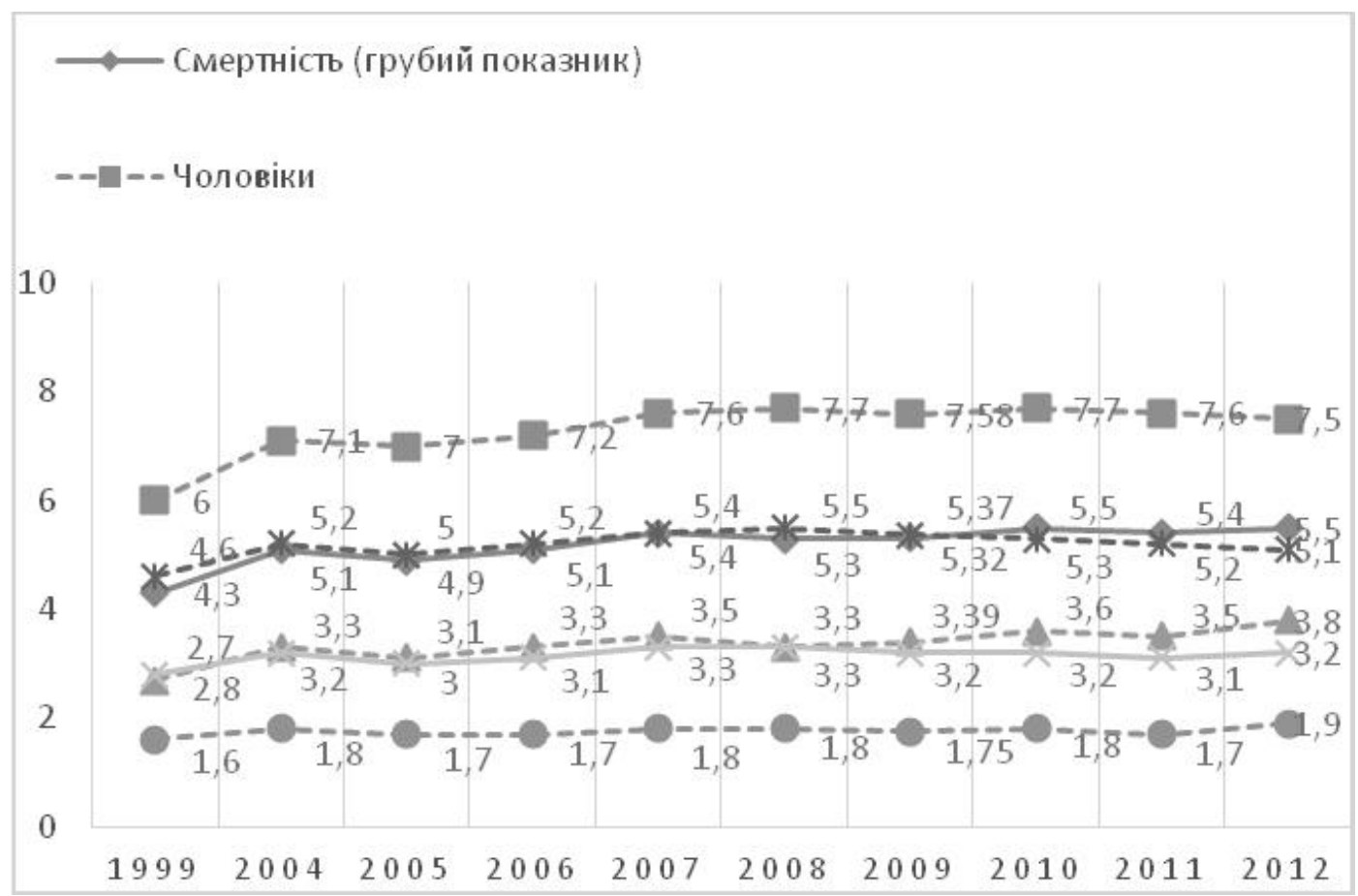

Рис. 2. Динаміка змін грубого та стандартизованого показників смертності з приводу НКР в Україні впродовж 19992012 pp. 
7,7, Луганській - 9,7, Черкаській - 10,1 областях. Детальну структуру динаміки змін цього показника відображено в таблиці 1.

Оцінка динаміки показника смертності із приводу НКР (український стандарт) у різних регіонах України дозволила встановити найвищі рівні летальності в Запорізькій - 7, Сумській - 6, Рівненській - 6,
Тернопільській - 5,9 та Полтавській - 5,9 областях. Найнижча смертність із приводу НКР була відмічена в Одеській - 3,7, Черкаській - 4, Закарпатській - 4,2 та Чернівецькій - 4,2 областях (табл. 2).

Показники захворюваності та смертності у хворих на НКР у 2012 р. в різних областях України представлено на рисунках 3 та 4.

Таблиця 1. Динаміка змін стандартизованого показника захворюваності (український стандарт) на НКР в Україні та її областях впродовж 1999-2012 рр.

\begin{tabular}{||l|c|c|c|c|c|c|c|c|c|c||}
\hline Україна, її області, АР Крим & 1999 & 2004 & 2005 & 2006 & 2007 & 2008 & 2009 & 2010 & 2011 & 2012 \\
\hline Україна & 8,1 & 9,4 & 9,8 & 9,8 & 10,8 & 11,2 & 10,82 & 11,2 & 11 & 12,1 \\
\hline АР Крим & 8,4 & 8,9 & 10,3 & 9 & 9,2 & 9,5 & 10,23 & 11,3 & 9 & 12,8 \\
\hline Вінницька & 5,6 & 8,6 & 10,7 & 8,8 & 11,7 & 9,3 & 10,85 & 13,1 & 10,6 & 11,4 \\
\hline Волинська & 7,2 & 9,8 & 9,6 & 11,2 & 10,7 & 8,5 & 13,51 & 11,6 & 8,9 & 12,5 \\
\hline Дніпропетровська & 8,9 & 9,8 & 10 & 10,2 & 10,7 & 11,5 & 11,51 & 11,3 & 9,7 & 12,5 \\
\hline Донецька & 8,6 & 8,3 & 8,4 & 9,2 & 10,1 & 10,6 & 9,61 & 10,5 & 10,8 & 10,9 \\
\hline Житомирська & 6,8 & 9,1 & 10,7 & 11,6 & 9,8 & 12 & 9,84 & 10,6 & 9 & 13,2 \\
\hline Закарпатська & 5 & 6,4 & 8,2 & 7,5 & 7,4 & 9 & 7,91 & 8,4 & 7,8 & 7,7 \\
\hline Запорізька & 7,6 & 8,6 & 9,8 & 9 & 11,8 & 14,9 & 11,09 & 12,4 & 12,5 & 12,4 \\
\hline Івано-Франківська & 6,3 & 8,1 & 8,7 & 9,3 & 9,9 & 10,5 & 8,8 & 9,4 & 10,6 & 11,3 \\
\hline Київська & 7,7 & 8,8 & 9,6 & 9,9 & 10,7 & 10,4 & 11,01 & 10,5 & 11,1 & 12,3 \\
\hline Кіровоградська & 6,5 & 9,4 & 9,6 & 9,7 & 11,9 & 11,5 & 13,51 & 11,6 & 15,6 & 13,8 \\
\hline Луганська & 6,3 & 9,9 & 9 & 8,5 & 9,9 & 10,5 & 10,09 & 10,4 & 9,4 & 9,7 \\
\hline Львівська & 7,5 & 10 & 8,9 & 9,1 & 10,1 & 11,4 & 10,98 & 12,1 & 13,2 & 12,1 \\
\hline Миколаївська & 8,4 & 10,3 & 10,9 & 11,6 & 10,9 & 12,6 & 11,2 & 10,9 & 10,1 & 14 \\
\hline Одеська & 9 & 9,8 & 9,7 & 9,8 & 11,4 & 10,4 & 12,12 & 11,7 & 13,9 & 11,1 \\
\hline Полтавська & 9,6 & 9,9 & 12,4 & 11,1 & 11,4 & 12,7 & 10,75 & 11,4 & 9,6 & 13,7 \\
\hline Рівненська & 8,9 & 13 & 12,1 & 11,3 & 12,2 & 16,2 & 12,33 & 12,2 & 7,6 & 13,7 \\
\hline Сумська & 7,7 & 8,8 & 10,1 & 9,8 & 12,1 & 10,4 & 12,59 & 11,6 & 11,1 & 15,5 \\
\hline Тернопільська & 8 & 10,6 & 8,8 & 8,8 & 10,2 & 11,1 & 8,25 & 9,7 & 8,4 & 11,7 \\
\hline Харківська & 12 & 9,3 & 10,4 & 10,4 & 12,5 & 11,6 & 10,64 & 10 & 12,7 & 13,2 \\
\hline Херсонська & 7,1 & 8,8 & 11 & 9,7 & 10,6 & 12,3 & 10,84 & 12,6 & 10,9 & 11,6 \\
\hline Хмельницька & 8,6 & 6,9 & 9,4 & 10,1 & 10,6 & 10,7 & 11,4 & 12,5 & 10,4 & 11,5 \\
\hline Черкаська & 7,9 & 9,6 & 10,2 & 8,9 & 10,6 & 11 & 8,79 & 11,7 & 13 & 10,1 \\
\hline Чернівецька & 7,6 & 6,6 & 6,2 & 6,7 & 9,4 & 8,4 & 10,51 & 7,4 & 12,3 & 7,6 \\
\hline Чернігівська & 13,5 & 7,7 & 7,8 & 11 & 10,4 & 9,6 & 11,24 & 11,2 & 9,4 & 12,2 \\
\hline \hline
\end{tabular}

Таблиця 2. Динаміка змін стандартизованого показника смертності (український стандарт) 3 приводу НКР в Україні та її областях впродовж 1999-2012 рр.

\begin{tabular}{||l|c|c|c|c|c|c|c|c|c|c||}
\hline \hline Україна, ії області, АР Крим & 1999 & 2004 & 2005 & 2006 & 2007 & 2008 & 2009 & 2010 & 2011 & 2012 \\
\hline Україна & 4,3 & 3,2 & 3 & 4,9 & 5,2 & 5,1 & 5,11 & 5,2 & 4,6 & 5,1 \\
\hline АР Крим & 2,1 & 2,5 & 2,3 & 4,1 & 3,7 & 3,9 & 3,75 & 4,7 & 3,3 & 4 \\
\hline Вінницька & 3,8 & 2,3 & 3 & 5,1 & 5,1 & 4 & 5 & 4,3 & 4,6 & 5,3 \\
\hline Волинська & 3,8 & 3,6 & 3,8 & 5,4 & 4,8 & 4,7 & 5,8 & 6 & 3,3 & 4,6 \\
\hline Дніпропетровська & 4,6 & 3 & 3,3 & 5,4 & 5,7 & 5,8 & 4,55 & 5,2 & 4,7 & 5 \\
\hline Донецька & 5,2 & 3,5 & 2,8 & 4,9 & 4,8 & 5,1 & 5,13 & 5,9 & 4,8 & 5,2 \\
\hline Житомирська & 3,8 & 3,5 & 3,5 & 5,5 & 6,5 & 4,8 & 4,71 & 5,6 & 5,2 & 5,6 \\
\hline Закарпатська & 3,4 & 2,3 & 3 & 4,4 & 3,1 & 4,8 & 4,51 & 4,4 & 2,8 & 4,2 \\
\hline Запорізька & 3,0 & 3,1 & 3 & 4,6 & 6,3 & 6,2 & 6,52 & 6 & 5,9 & 7 \\
\hline Івано-Франківська & 3,2 & 2,9 & 2,8 & 4,5 & 4,6 & 4,2 & 5 & 4,1 & 5,6 & 4,7 \\
\hline Київська & 4 & 3,2 & 2,6 & 4,6 & 5,7 & 5,2 & 5,45 & 4,9 & 4,9 & 4,9 \\
\hline Кіровоградська & 3,5 & 3,4 & 3,1 & 3,8 & 5,4 & 5,7 & 5,45 & 5,7 & 5,1 & 5 \\
\hline \hline
\end{tabular}


Таблиця 2. Динаміка змін стандартизованого показника смертності (український стандарт) з приводу НКР в Україні та її областях впродовж 1999-2012 pр.

\begin{tabular}{||l|c|c|c|c|c|c|c|c|c|c||}
\hline \hline Україна, її області, АР Крим & 1999 & 2004 & 2005 & 2006 & 2007 & 2008 & 2009 & 2010 & 2011 & 2012 \\
\hline Луганська & 3,7 & 3,3 & 3,9 & 4,7 & 5,5 & 5,2 & 5,84 & 6,2 & 4,5 & 5 \\
\hline Львівська & 4,2 & 3,3 & 2,7 & 4,6 & 4,3 & 4,4 & 4,94 & 4,3 & 4,3 & 4,9 \\
\hline Миколаївська & 4,4 & 2,9 & 2,6 & 3,9 & 4,7 & 7,5 & 6,26 & 4,9 & 4,1 & 5,8 \\
\hline Одеська & 5,5 & 2,8 & 2,8 & 4,6 & 5,4 & 5,3 & 4,38 & 5 & 4,3 & 3,7 \\
\hline Полтавська & 4,1 & 3,2 & 4,6 & 5,7 & 5,3 & 6,3 & 6,01 & 5,1 & 5 & 5,9 \\
\hline Рівненська & 4 & 4,2 & 4,4 & 5,9 & 5,1 & 7,9 & 5,46 & 6,7 & 4,9 & 6 \\
\hline Сумська & 4 & 3,4 & 3,1 & 6,1 & 4,7 & 5,4 & 5,27 & 5,8 & 5,5 & 6 \\
\hline Тернопільська & 4,5 & 3,6 & 2,6 & 4,8 & 5,4 & 5,2 & 5,23 & 5,1 & 5,5 & 5,9 \\
\hline Харківська & 6,3 & 3,1 & 2,5 & 4,6 & 5 & 4,9 & 4,78 & 4,2 & 5,1 & 5,5 \\
\hline Херсонська & 3,2 & 3,8 & 3,3 & 4,8 & 5,1 & 3,7 & 4,68 & 5,5 & 4,7 & 5,1 \\
\hline Хмельницька & 3,2 & 2,9 & 2,7 & 4,5 & 5,3 & 4,9 & 3,89 & 4,5 & 5,2 & 5 \\
\hline Черкаська & 3,7 & 2,8 & 2,8 & 5,8 & 5,6 & 4,8 & 5,53 & 4,6 & 4,3 & 4 \\
\hline Чернівецька & 4,3 & 2,2 & 2,4 & 2,9 & 4,9 & 3,8 & 4,76 & 5 & 5,2 & 4,2 \\
\hline Чернігівська & 6,2 & 3 & 2,8 & 4,7 & 5,6 & 4,2 & 4,97 & 4,5 & 3,8 & 5 \\
\hline \hline
\end{tabular}

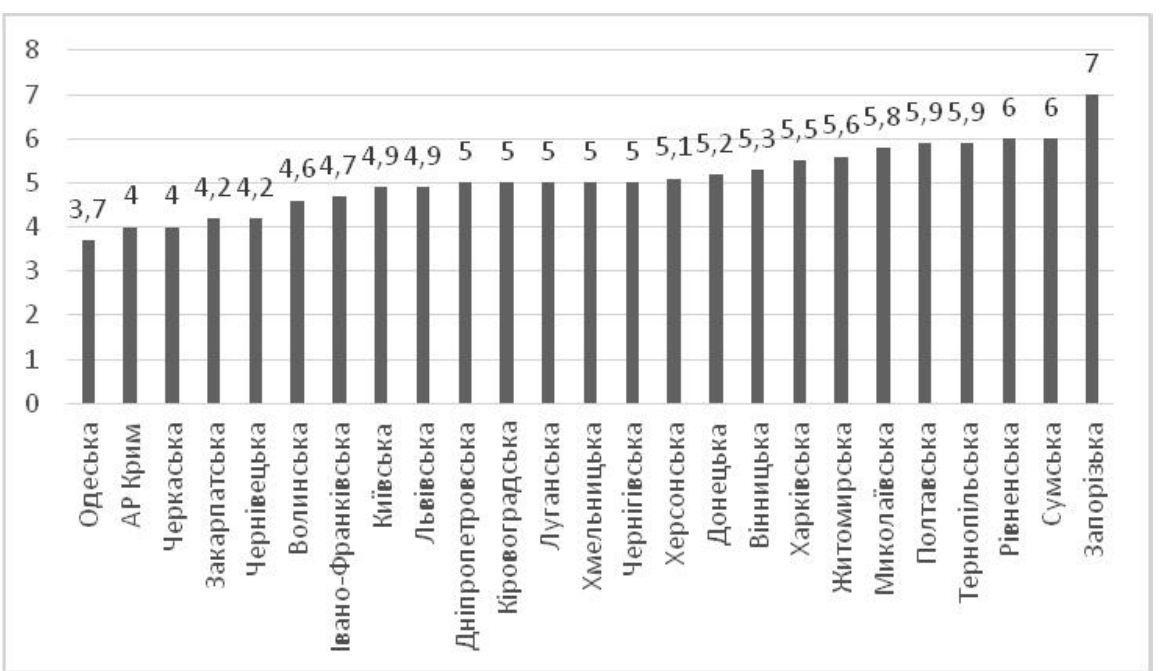

Рис. 4. Рейтинг областей України за стандартизованим показником смертності (український стандарт) на НКР у 2012 p.

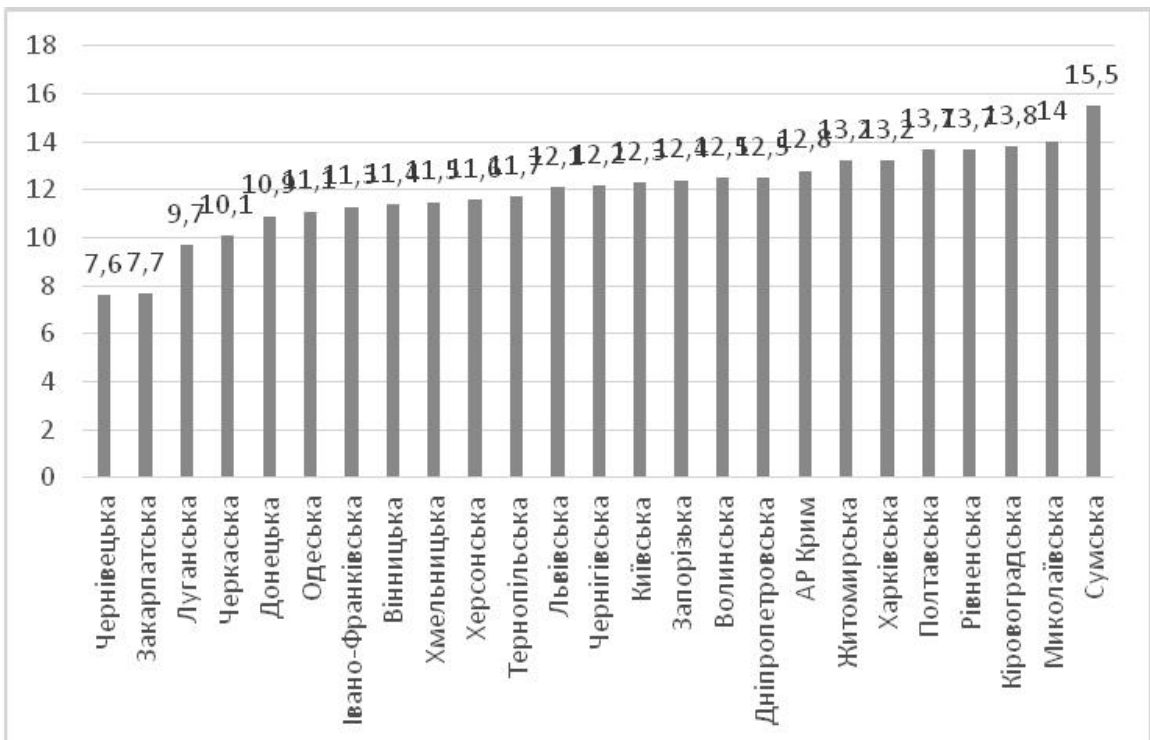

Рис. 3. Рейтинг областей України за стандартизованим показником захворюваності (український стандарт) на НКР y 2012 p. 


\section{СОЦІАЛЬНА ГІГІЕНА ТА ОХОРОНА ЗДОРОВ'Я}

Висновки. 1. Проведений аналіз динаміки показників захворюваності на НКР у 1999-2012 рр. продемонстрував їх зростання як в Україні в цілому, так і в кожній окремій області. У 1999 р. показник захворюваності (світовий стандарт) на НКР в Україні становив 5,6, а в 2012 р. - 8,1. При цьому в чоловіків даний показник перевищував такий у жінок у середньому в 2 рази.

2. Аналіз динаміки показників смертності внаслідок НКР у 1999-2012 рр. засвідчив чітку тенденцію до їх зростання по Україні в цілому та в кожній окремій області. В 1999 р. показник смертності (світовий

\section{СПИСОК ЛІТЕРАТУРИ}

1. Рак в Україні, 1999-2013. Бюл. Нац. канцер-реєстру України. - К., 2013. - № 8. - С. 49-50.

2. Анализ урологической заболеваемости в Российской Федерации в 2002-2009 годах по данным официальной статистики [Электронный ресурс] / Аполихин О. И., Сивков А. В., Бешлиев Д. А. [и др.] // Урологическая заболеваемость и смертность в Российской Федерации. - 2011. - Режим доступа : www.oncouro.ru.

3. Давыдов М. И. Заболеваемость злокачественными заболеваниями и смертность от них населения стран СНГ в 2007 г. / М. И. Давыдов, Е. М. Аксель // Вестник РОНЦ им. Н. Н. Блохина РАМН. - 2009. - 20 (3), прил. 1. - С. 52-116.

4. Estimates of worldwide burden of cancer in 2008: GLOBO- стандарт) внаслідок НКР в Україні становив 2,8, а в 2012 р. - 3,2. При цьому даний показник був майже в 3 рази вищий у чоловіків, ніж у жінок.

3. У результаті проведеного дослідження було встановлено чітку тенденцію до зростанняпоказників захворюваності та смертності у хворих із НКР в Україні та ії областях із 1999 до 2012 р. При цьому спостерігали гендерні особливості - у чоловіків обидва показники значно перевищували такі в жінок. Невпинне зростання захворюваності та смертності у хворих із НКР потребує перегляду протоколів обстеження та лікування такої категорії хворих.

CAN 2008 / J. Ferlay, H-R. Shin, F. Bray [et al.] // Int. J. Cancer. - 2010. - Vol. 127(12). - P. 2893-2917.

5. Cancer survival and incidence from the Surveillance, Epidemiology, and End Results (SEER) program / L. A. Gloeckler Ries, M. E. Reichman, D. R. Lewis [et al.] // Oncologist. - 2003. Vol. 8(6). - P. 541-552.

6. Global cancer statistics / A. Jemal, F. Bray, M. M. Center // CA Cancer J. Clin. - 2011. - Vol. 61(2). - P. 69-90.

7. Cancer statistics / A. Jemal, R. Siegel, J. Xu, E. Ward 2010 // CA Cancer J. Clin. - 2010. - Vol. 60(5). - P. 277-300.

8. Siegel R. Cancer statistics, 2012 / R. Siegel, D. Naishadham, A. Jemal // CA Cancer J. Clin. - 2012. - Vol. 62(1). - P. 10-29.

Отримано 26.01.15 